\title{
The Effect of Increasing Surface Area of Graphite Electrode on the Performance of Dual Chamber Microbial Fuel Cells
}

\author{
Pedy Artsanti*, Sudarlin, Eka Fadzillah Kirana \\ Chemistry Department, Faculty of Science and Technology, UIN Sunan Kalijaga Yogyakarta \\ J1. Marsda Adisucipto No 1 Yogyakarta 55281, Indonesia. Tel. +62-274-540971, Fax. +62-274-519739. \\ *Email: pedy_artsanti2003@yahoo.com
}

\begin{abstract}
Artsanti P, Sudarlin, Kirana E F. 2017. The Effect of Increasing Surface Area of Graphite Electrode on the Performance of Dual Chamber Microbial Fuel Cells. Proc Internat Conf Sci Engin 1: 137-140. The effect of increasing surface area of graphite electrode on the performance of dual chamber Microbial Fuel Cells (MFC) was observed. The surface area of graphite electrode (anode and cathode) that was using in this experiment was $29.5 \mathrm{~cm}^{2}$ and $44.5 \mathrm{~cm}^{2}$ for the A and B reactor, respectively. The anode chamber contained mixed microorganism culture from real wastewater of textile industry and the cathode chamber contained $0.1 \mathrm{M}$ potassium permanganate electrolyte solution. The salt bridge was required to stabilize the charge between the anode and cathode chambers, and the electrodes attached to the anode and cathode chambers as the electron catcher. Both, the A and B reactor were observed for 72 hours of running time. The voltage and power density were found to increase with the increase in surface area of the graphite electrode. The highest power density was $93.93 \mathrm{mWm}^{-2}$ and $197.23 \mathrm{mWm}^{-2}$ that obtained at 36 hours and 48 hours on the A and B reactor, respectively. At the end of experiment, these MFCs system could also reduce COD by $28.6 \%$ and $15.6 \%$ on A and B reactor, respectively.
\end{abstract}

Keywords: Microbial Fuel Cell, surface area of electrode, power density, COD

\section{INTRODUCTION}

Microbial Fuel Cells (MFCs) are a type of fuel cell that converts chemical energy to electrical energy through the action of microorganism as biocatalysts as described by Lovley (2006). Microbial Fuel Cells (MFCs) are regarded as a promising future technology for wastewater treatment for the several reasons. Firstly, MFCs are able to harvest energy from organic matters and treat wastewaters at the same time. Secondly, a wide range of organic wastewaters can be treated by MFCs, if proper electricity-producing bacteria were enriched in the anode. Wastewaters that are rich in organic matters are all great biomass sources for MFCs, such as wastewater of textile industries and wastewater of tempe industries (Kirana, E.F., 2017; Utami et. al., 2014). The opportunity of MFCs development is still a challenge since the number of industries producing waste in Indonesia is increasing from year to year. In this research, the wastewater used was from textile industry of PT. Samitex Sewon. The utilization of textile wastewater as a substrate in the MFCs system, hopefully, can be one of alternative solution of wastewater treatment that can also overcome the problems caused by wastewater, the environmental pollution that often leads to horizontal conflicts between industry and surrounding communities. In addition, the results of this research are also expected to be one step ahead to get a cheap energy source (Kirana, E.F., 2017). While MFCs hold great potentials for various applications, major challenges remain for MFCs to be practical. The power densities of MFCs must be augmented because they are too low for most envisioned application.
MFCs are being constructed using a variety of materials, and in an ever increasing diversity of configurations. These systems are operated under a range of conditions that include differences in temperature, $\mathrm{pH}$, electron acceptor, electrode surface areas, reactor size, and operation time. Many different configurations are possible for MFCs. A widely used and inexpensive design is a two chamber MFCs built in a traditional " $\mathrm{H}$ " shape, consisting usually of two chambers connected by a tube containing a separator which is usually a proton exchange membrane (PEM) or a plain salt bridge (Min, B. et al.. 2005). The simplest materials for anode electrodes are graphite plates or rods as they are relatively inexpensive, easy to handle, and have a defined surface area.

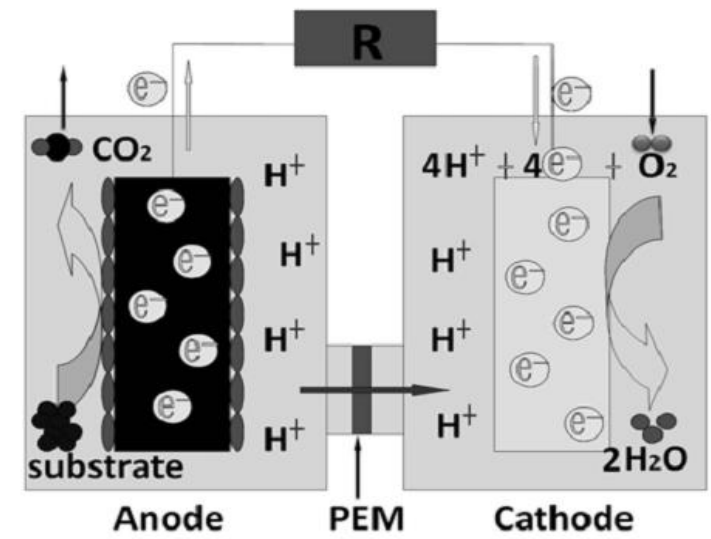

Figure 1. Schematic diagram of a typical two-chamber MFC (K. Guo et al., 2012).

Lorenzo et al. (2010) showed that the power output of MFCs depends strongly on the electrode surface 
properties. This can be explained that the anode material and its configuration influences the development of the microbial community involved in the electrochemical bio-reactions. Sinaga et al. (2014) was compared four electrodes with different surface area on MFCs system using $1 \mathrm{M} \mathrm{KCl}$ and 5\% Agar as salt bridge. The results showed that the highest surface area of graphite electrodes generated the highest voltage. According to these, this research was designed to find out the effect of increasing surface area of graphite electrode on the performance of dual chamber Microbial Fuel Cells (MFC).

\section{MATERIALS AND METHODS}

The MFCs tool in this study uses electrochemical cells with dual chamber system consisting of cathode and anode compartments, using two reactors with $2000 \mathrm{~mL}$ reactor capacity. The electrolyte solution used was a solution of Potassium Permanganate 0.1 M. The anode and cathode chambers connected with a salt bridge using PVC pipe (length $=10 \mathrm{~cm}$; diameter $=2.5 \mathrm{~cm}$ ). This salt bridge membrane is made by dissolving $2.5 \mathrm{~g}$ Nutrient Agar in $100 \mathrm{~mL}$ of $1 \mathrm{M} \mathrm{KCl}$ solution, stirring it until boiling on hotplate. The experiment was carried out for 72 hours.

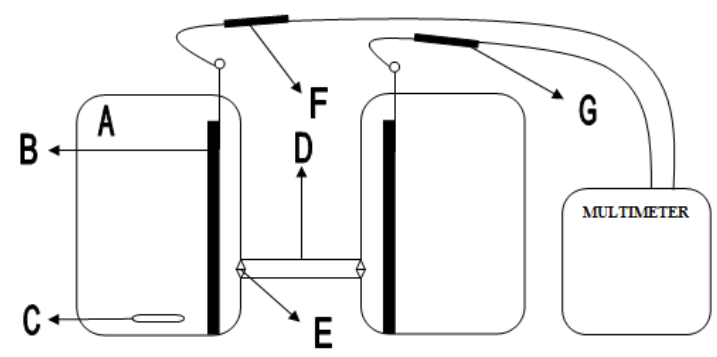

Information:

A. Reactors capacity $2000 \mathrm{~mL}$

B. Graphite electrode size $0.5 \times 1.5 \times 7 \mathrm{~cm}$ for $\mathrm{A}$ reactor and $0.5 \times 2.5 \times 7 \mathrm{~cm}$ for $\mathrm{B}$ reactor.

C. Magnetic stirrer

D. Pipe with diameters $2.5 \mathrm{~cm}$ and length $10 \mathrm{~cm}$

E. Watermurr

F. Connection with negative electrode

G. Connection with positive electrode

Figure 2. Dual chamber Microbial Fuel Cells.

\section{RESULTS AND DISCUSSION}

\section{Optical Density (OD) and pH}

The absorbance measurements were performed during the running of the MFCs system reactor. Spectrophotometer can be used to measure the turbidity of an object through the value of Optical Density (OD). This method is often used to estimate the amount or mass of cells, one of which is microbial cells in solution (Novitasari, 2011). Optical Density (OD) derived from absorbance measurements of this experiment is shown in Figure 3.

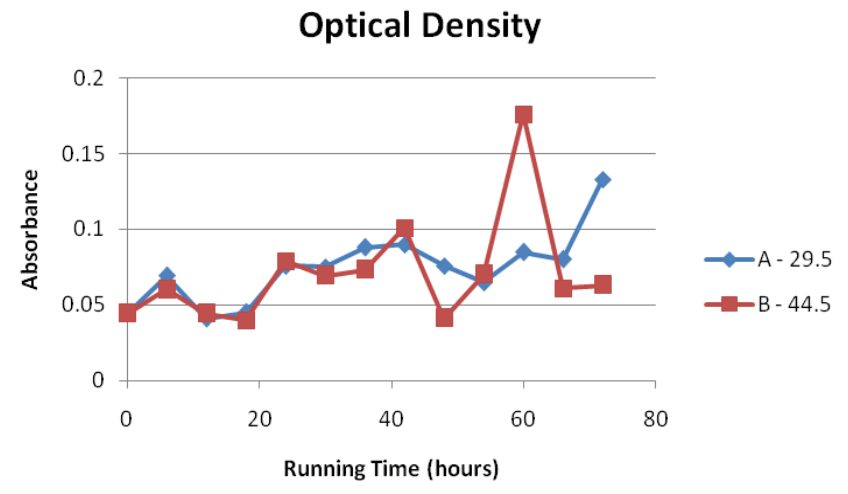

Figure 3. Optical density of MFCs - A $\left(29.5 \mathrm{~cm}^{2}\right)$ and B $\left(44.5 \mathrm{~cm}^{2}\right)$.

The OD of both (A and B) MFCs system show a tendency to increase, even though only slightly. This phenomenon indicates that there is a tendency in increasing the number of microbial cells in the system (Novitasari, 2011). In addition, this results are in line with the results of $\mathrm{pH}$ monitoring as shown in Figure 4 with the average value are 5.9 and 5.5 for $\mathrm{A}$ and $\mathrm{B}$, respectively.

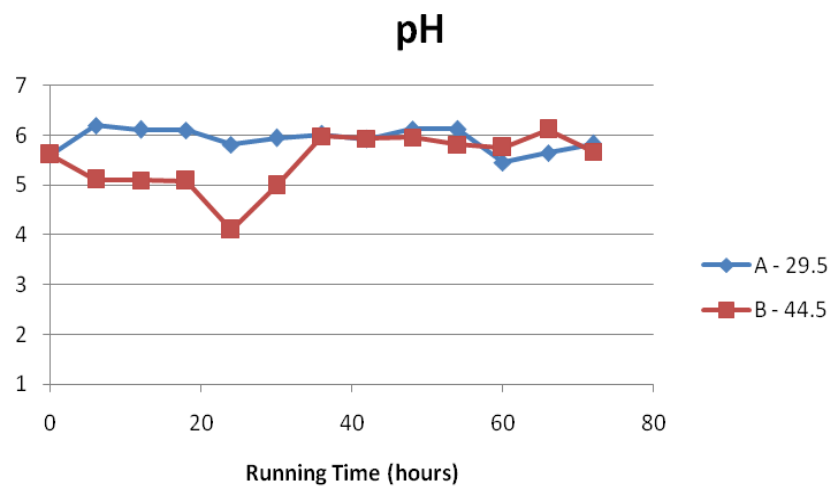

Figure 4. The $\mathrm{pH}$ of MFCs $-\mathrm{A}\left(29.5 \mathrm{~cm}^{2}\right)$ and $\mathrm{B}\left(44.5 \mathrm{~cm}^{2}\right)$.

Most microorganism prefer a neutral medium with a maximum activity in the range of $\mathrm{pH}$ 6-8 (Artsanti, P., 2005). The value of OD that indicating an increase in the number of microbial cells in these MFCs system was affirmed by the value of $\mathrm{pH}$ during 72 hours of experiment. This result is in agreement with the observations made by Artsanti, P., et al. (2005), which indicated the favorable condition for the activities of almost all microbial species.

\section{Voltage and Power Density}

MFCs are able to convert the chemical energy stored in the chemical bonds of organic compounds into electricity. However, so far, the power produced by MFCs is still too low to be useful in most applications. The results of voltage monitoring during 72 hours of experiment is shown in Figure 5. The voltage of A reactor (with the electrode surface area of $29.5 \mathrm{~cm}^{2}$ ) 
tends to drop at the first 6 hours, then increase significantly until the $24^{\text {th }}$ hour. After 24 hours, the voltage of A reactor tends to drop. The similar trend of the results of voltage monitoring shows by $\mathrm{B}$ reactor (with the electrode surface area of $44.5 \mathrm{~cm}^{2}$ ). At the first 12 hours, the voltage of $\mathrm{B}$ reactor had increased, then was relatively constant until the $24^{\text {th }}$ hour. The highest voltage, 0.93 volt, was obtained at $24^{\text {th }}$ hour. After 24 hours, the voltage of $\mathrm{B}$ reactor tends to drop to the lowest point, 0.49 volts, at the end of experiment. Figure 5 shows that the voltage of $\mathrm{B}$ reactor is higher than $\mathrm{A}$ reactor from the beginning to the end of the experiment. This phenomenon indicate that the surface area of the electrode affects the resulting voltage. Similar phenomenon was reported by Lorenzo et. al. (2010).

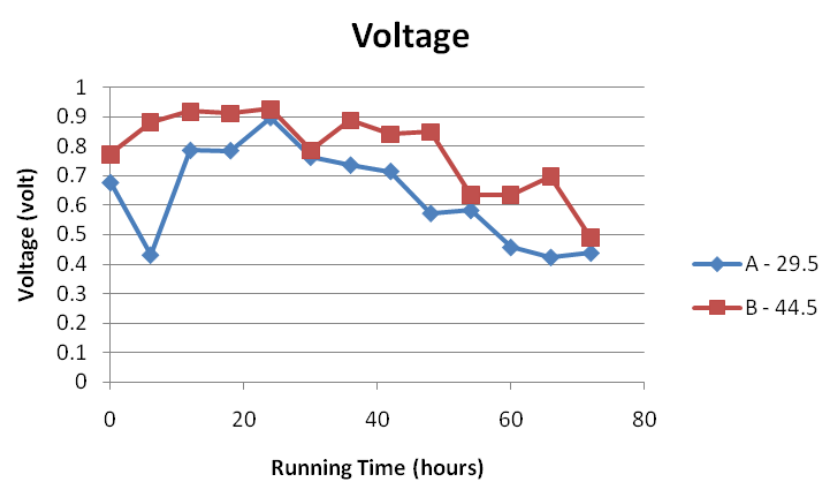

Figure 5. The voltage generated from MFCs system - A $\left(29.5 \mathrm{~cm}^{2}\right)$ and B $\left(44.5 \mathrm{~cm}^{2}\right)$.

The value of power density in this experiment (Figure 6) represent the production of electricity generated by MFCs system. The highest power density was $93.93 \mathrm{mWm}^{-2}$ and $197.23 \mathrm{mWm}^{-2}$ that obtained at 36 hours and 48 hours on the $\mathrm{A}$ and $\mathrm{B}$ cell, respectively. Figure 6 shows that the power density of $\mathrm{B}$ reactor is higher than A reactor from the beginning to the end of the experiment. The average power density generated from MFCs system is $37.4 \mathrm{~mW} / \mathrm{m}^{2}$ and $120 \mathrm{~mW} / \mathrm{m}^{2}$ for $\mathrm{A}$ and $\mathrm{B}$ reactor, respectively. It reveals that the larger the surface area of the electrode, the higher the power density generated.

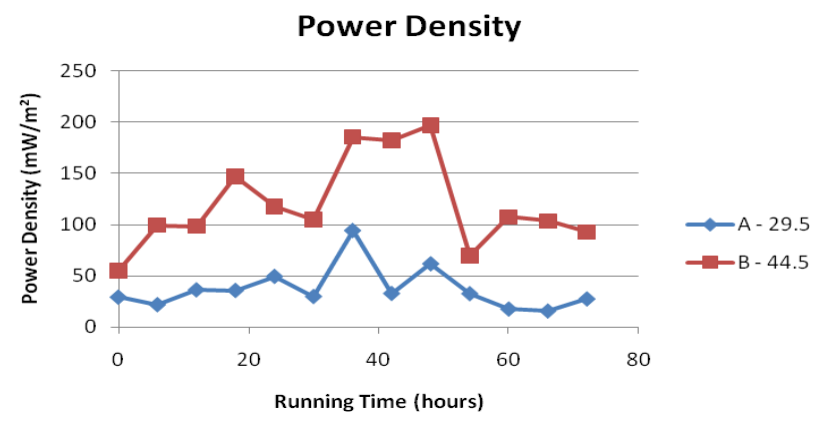

Figure 6. Power density generated from MFCs system - A $\left(29.5 \mathrm{~cm}^{2}\right)$ and B $\left(44.5 \mathrm{~cm}^{2}\right)$.
According to Sadeqzadeh et.al. (2012) the large electrode surface area will capture more electrons on its surface to produce greater electrical energy. In this experiment, it can be explained that the large quantities of electrons produced by microorganism cannot be directly channeled to the outer circuit due to the limited space to attach to the electrode in a reactor, so there is an electrons queue and the process must be gradual, resulting lower power density. In B reactor, the surface area of electrode is larger than a reactor. Apparently, most electrons produced by microorganism can attach to the electrode and directly channeled to the outer circuit, resulting higher power density.

In general, this experiment shows relatively low power density of MFCs system. It may due to the complexity of electron transfer mechanisms of microorganism or bacteria used in MFCs system. The oxidation of organic material produces both protons and electrons. The electrons are removed instantaneously via the conductive biofilm and the electrical circuit of the MFCs. The larger protons have to migrate out of the biofilm to the cathode. This occurs at a much slower rate and may cause a bottleneck inhibiting power production (Franks, A.E., and Nevin, K.P., 2010).

\section{Chemical Oxygen Demand (COD)}

COD is one of commonly-used organics removal parameters. COD test measures the total organic carbon with the exception of certain aromatics, such as benzene, which are not completely oxidized in the reaction. COD is based on the fact that nearly all organic compounds can be fully oxidized to carbon dioxide with a strong oxidizing agent, such as potassium dichromate under acidic conditions. The COD value thus represents almost $100 \%$ of the total organics present (Onyia, 2002).

The COD concentration of $\mathrm{A}$ and $\mathrm{B}$ reactor of MFCs system is shown in Figure 7. It shows that at the end of experiment, these MFCs systems could reduce COD by $28.6 \%$ and $15.6 \%$ on A and B reactor, respectively. This confirms the role of MFCs in wastewater treatment by removing COD. Even though, the percentage of COD removal of MFCs system in this experiment is relatively low. It may be due to textile wastewater used in this system. The textile wastewater may contain an organic compound that is not completely decomposed. In particular textile wastewater, microbes generally require considerable time in breaking up complex organic compounds (Van der Maarel et. al., 2002). In addition, the influent concentration of organic matter comprising COD in this experiment is relatively high, $6518.5 \mathrm{mg} / \mathrm{L}$ and $5517.5 \mathrm{mg} / \mathrm{L}$ for $\mathrm{A}$ and $\mathrm{B}$ reactor, respectively. It seems that this factor also contribute to the low percentage of COD removal. 


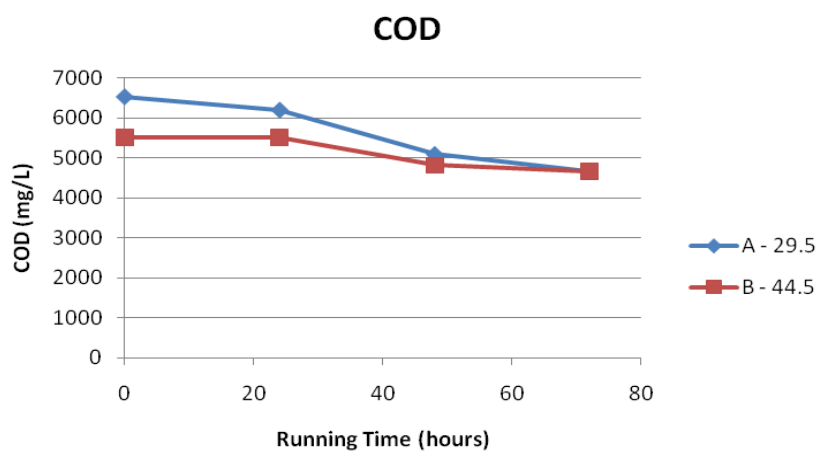

Figure 7. COD concentration of MFCs system - A $\left(29.5 \mathrm{~cm}^{2}\right)$ and B $\left(44.5 \mathrm{~cm}^{2}\right)$.

Logan et. al. (2006) reported similar result that the success of specific MFCs applications in wastewater treatment will depend on the concentration and biodegradability of the organic matter in the influent, the wastewater temperature, and the absence of toxic chemicals.

\section{CONCLUSIONS}

MFCs are a promising technology for the production of electricity from organic waste material. In general, this experiment shows relatively low power density of MFCs system. The average power density generated from MFCs system is $37.4 \mathrm{~mW} / \mathrm{m}^{2}$ and $120 \mathrm{~mW} / \mathrm{m}^{2}$ for A and $\mathrm{B}$ reactor, respectively. The voltage and power density were found to increase with the increase in surface area of the graphite electrode. The highest power density was $93.93 \mathrm{mWm}^{-2}$ and $197.23 \mathrm{mWm}^{-2}$ that obtained at 36 hours and 48 hours on the A and B reactor, respectively. At the end of experiment, these MFCs system could also reduce COD by $28.57 \%$ and $15.61 \%$ on A and B reactor, respectively.

\section{ACKNOWLEDGEMENTS}

The authors acknowledge the Chemistry Department of Faculty of Science and Technology, State Islamic University Sunan Kalijaga, Yogyakarta, Indonesia for providing the opportunity of this research work. We also acknowledge sincere thanks to Karmanto, M.Sc for his advices.

\section{REFERENCES}

Artsanti, P., 2005, Performance Comparison of Laboratory-Scale Unvegetated Subsurface-Flow Constructed Wetland System With Different Media For Treating Landfill Leachates, Thesis, Universiti Sains Malaysia.

Artsanti, P., Ahmad, Md.N., P.E. Lim., H.L.H. Chong., Kamil, A.A., 2005, Comparison of Different Filter Media in NonVegetated Subsurface-Flow Constructed Wetlands for the Treatment of COD of Landfill Leachate, Indonesian Journal on Environmental Chemistry and Toxicology, Vol. 4. No. 1., 29-39.

Franks, A.E and Nevin, K.P., 2010, Microbial Fuel Cells, A Current Review, Energies 3, 899-919

K. Guo, D. J. Hassett, T. Gu., 2012, "Microbial Fuel Cell: Electricity Generation from Organic Waste by Microbes," Chapter 9 in Microbial Biotechnology: Energy and Environment edited by R. Arora, pp. 162-189, CAB International, Oxon, United Kingdom.

Kirana, E.F., 2017, Pemanfaatan Mikroba Dalam Limbah Cair Industri Tekstil Sebagai Penghasil Elektron Pada Sistem Dual-Chamber Microbial Fuel Cell (MFC).

Lorenzo, M.D., Scott, K., Curtis, T.P., Head, I.M., 2010, Effect of Increasing Anode Surface Area on the Performance of a Single Chamber Microbial Fuel Cell, Chemical Engineering Journal156, 40-48.

Lovley, D.R., 2006, Microbial fuel cells: Novel microbial physiologies and engineering approaches. Curr. Opin. Biotechnol, 17: 327-332. DOI:10.1016/j.copbio.2006.04.006

Min, B.; Cheng, S.; Logan, B. E. Electricity generation using membrane and salt bridge microbial fuel cells. Water Res.2005, 39, 1675-1686.

Novitasari, D., Optimasi Kinerja Microbial Fuel Cell (MFC) untuk Produksi Energi Listrik Menggunakan Bakteri Lactobacillus bulgaricus. Skripsi 2011, Fakultas Teknik. Depok: Universitas Indonesia.

Onyia, C.O., 2002, Biological Nitrogen Removal Processes From Industrial Wastewaters: The Case for Palm Oil Mill Effluent, Dissertation, Universiti Sains Malaysia

Sadeqzadeh, M., Ghasemi, M., Jafary, T., Wan Daud, W. R., Ghannadzadeh, A., Salamatinia, B., Aly Hassan, S. H., 2012, Mass Transfer Limitation in Different Anode Electrode Surface Areas on the Performance of Dual Chamber Microbial Fuel Cell, American Journal of Biochemistry and Biotechnology, 8 (4) : 320 -325.

Sinaga, D. H., Suyati, L. dan Agustina, L. N. A., 2014, Studi Pendahuluan Pemanfaatan Whey Tahu sebagai Substrat dan Efek Luas Permukaan Elektroda dalam Sistem Microbial Fuel Cell, Jurnal Sains dan Matematika 22 (2): 30 - 35.

Utami, T.S., Arbianti, R., Novitasari, D., Kristin, E., Citrasari, A.E., 2014, Effect of Electrolytes and Microbial Culture toward Electricity Generation Utilizing Tempe Wastewater in Microbial Fuel Cell, Proceeding of The $5^{\text {th }}$ Sriwijaya International Seminar on Energy and Environmental Science \& Technology, Palembang, Indonesia.

Van der Maarel, M.J.E.C., B. Van der Veen, J. C. M. Uitdehaag, H. Leemhuis, L. Dijkhuizen, 2002, Properties and Appications of Starch - converting Enzymes of the a Amylase Family. J. Biotechnol. 94: 137 - 155. 